\title{
TOWARDS BETTER INVOLVEMENT IN GREEN BANKING PRACTICES: EVIDENCE FROM ROMANIA
}

\author{
BAICU Claudia Gabriela ${ }^{1}$ \\ ${ }^{1}$ Institute for World Economy, Romanian Academy, baicuclaudia70@yahoo.ro
}

\begin{abstract}
The European Green Deal has re-ignited the imperative of green finance that is called to support the European Union transition to a greener economy. Green finance becomes even more opportune in the context of the economic recovery after the COVID-19 pandemic. The aim of the paper is to explore green banking practices in the Romanian banking system. The investigation reveals the efforts of banks to be environmentally friendly and to be involved in financing of some green projects, such as the energy efficient projects. Nevertheless, the green banking products are still in the emerging stage and banks in Romania should develop their role in the field, by diversifying the range of green products and services, improving the expertise to assess green projects or intensifying the marketing initiatives to promote green products. In order to encourage banks in Romania to provide green financing several incentives should be conceived; similar to banks, the borrowers seeking green projects should be rewarded. Some mandatory requirements for banks to be involved in green investments may promote green banking in Romania. An essential condition to achieve the development of green banking in Romania is to increase awareness towards environmentally friendly behaviour at all levels.
\end{abstract}

KEY WORDS: Green banking, sustainable finance, European Green Deal, green financing, Romania

\section{INTRODUCTION}

To achieve the goals of the Paris Agreement on climate change and the UN 2030 Agenda for Sustainable Development urgent actions, including development of green finance, should be taken. The European Green Deal emphases the importance of green finance for transition to a greener economy at the European Union (EU) level.

Following the adoption of the Paris Agreement and Sustainable Development Goals, in 2016, the European Commission established an EU High-Level Expert Group on Sustainable Finance (HLEG) to provide advice on how to build a European strategy on sustainable finance (European Commission, 2016). According to the HLEG, "sustainable finance is about two imperatives": (i) improving "the contribution of finance to sustainable and inclusive growth as well as the mitigation of climate change" and (ii) strengthening financial stability (HLEG, 2018). By referring to banking lending to the green sector, the HLEG (2018) debated the arguments and the conditions for a "green supporting factor" to lower capital requirements for this asset class.

Therefore, the goals of the Action Plan on the EU strategy for sustainable finance include the shift of capital towards sustainable activities and better incorporation of sustainability issues related to risks associated with environmental factors in the prudential requirements of banks (European Commission, 2018).

Against this backdrop, the goal of the paper is to investigate green banking practices in the Romanian banking system, the most important part of the financial system. The paper examines these practices not only from the perspective of financing green projects but also from the perspective of actions undertaken by banks in their activities to protect environment.

The paper results are based on literature review, the annual reports issued by the most important banks in Romania and their web-sites investigation. Taking into consideration that the Romanian banking system is dominated by the credit institutions with majority foreign capital, the research required the examination of the sustainability policy at the international financial group level. The credit line facilities provided by the European Bank for Reconstruction and Development for financing green technologies in Romania were part of the analysis too.

\section{LITERATURE REVIEW}

There is no unique definition of green finance in the literature; moreover, there are other related terms, such us sustainable finance or climate finance, which requires some conceptual delimitation. Therefore, in order to draw distinction among these terms, several relevant definitions are presented below.

G20 Green Finance Study Group defines green finance as: "financing of investments that deliver environmental benefits in the broader context of environmentally sustainable development. These environmental benefits include, for example, reductions in air, water and land pollution, reductions in greenhouse gas emissions, improved energy efficiency while utilizing natural resources, as well as mitigation of and adaption to climate change and their co-benefits" (G20 Green Finance Study Group, 2016, p. 26).

Green finance concept is approached by Wang and Zhi (2016, p. 311) in a similar way: "Green finance is a phenomenon that combines the world of finance and business with environmentally friendly behaviour".

The literature uses the concept of climate finance to delimitate, within the broader concept of green finance, only the issues related to climate change: "Climate finance is merely one aspect of green finance, which is particularly focused on adaptation to the impacts of climate change or the reduction or limitation of greenhouse gas emissions" (Lindenberg, 2014, p. 2).

In the view of the European Commission, " 'Sustainable finance' generally refers to the process of taking due account of environmental and social considerations in investment decisionmaking, leading to increased investments in longer-term and sustainable activities" (European Commission, 2018, p. 3). 
The relationship between sustainable finance, green finance and climate finance is underscored by UNEP Inquiry (2016) that considers sustainable finance a broader term, which includes green finance and climate finance: "Although the terms are not always used consistently, in general a distinction can be drawn between approaches to sustainable finance that take a broad environmental, social, economic and governance approach, and those that take a narrower, 'green finance' one concerned only with environmental issues. Even more narrowly focused are those targeted only on climate change mitigation and/or adapting to climate change impacts" (UNEP Inquiry, 2016, p. 10).

The literature on green finance and green banking include several papers concerning the context of the emerging economies. The paper of Tara, Singh and Kumar (2015) analyses the green banking in India, stressing the importance banks in this country should give to environment protection. By referring to the BRICS countries, the study of Ngong and Thaddeus (2020) explores the relationship between climate changes and green banking. According to their findings, "green banking development increases with the increase in carbon dioxide emission, renewable energy used and government effectiveness" (p. 11).

Mohd and Kaushal (2018) underline the importance of green financing for the reducing of greenhouse gas emissions, contributing to the development of a country.

Kandavel (2013) provides some "tips for effective green banking". The suggestions of the author include: adoption of strategic plan for environment protection; use of online banking; waste management; financing of green projects.

A recent paper - Park and Kim (2020) - brings more clarity on the role that both financial institutions and regulators play in transition towards green banking. While financial institutions have developed green instruments, regulators could promote green banking through the control they can exert on banking system. The study also underlines that there are different approaches in green banking policy. Green activities promoted by banks in developed countries are based on voluntary code of conduct, while in developing countries on regulatory framework.

There is no extensive literature on green banking in Romania. However, there are some papers that include environmental protection issues in their analysis related to the corporate social responsibility (CSR) practices. For example, Frecea and Schipor (2017) present the CSR practices in two of the most important banks in Romania - the Romanian Commercial Bank and the BRD-Groupe Société Générale. Bădulescu, Bădulescu and Morutan (2017) is another study on sustainability issues in the Romanian banking system that should be mentioned. The authors conclude that banks in Romania approached the environmental issues in two ways: (1) they reduced their impact on environment and (2) included environmental criteria in their credit assessment procedures. Recently, NBR (2020) highlights the impact of climate risks - including the risk related to the transition towards a low-carbon economy - on financial stability in Romania.

\section{GREEN BANKING PRACTICES IN THE ROMANIAN BANKING SYSTEM}

The financial system in Romania is dominated by banking sector that accounts for $75 \%$ of total financial system assets at end2019. There are 34 banks, including seven foreign bank branches. Credit institutions with foreign private capital hold the most important part of the banking assets $-73.7 \%$ (NBR, 2020).

The prevalence of the foreign capital in the Romanian banking system reveals the strong links between the Romanian banking system and the international financial groups, with impact on sustainable policy developed by the local banks.

The top five banks in Romania - Banca Transilvania, Banca Comercială Română, BRD-Groupe Société Générale, ING Bank N.V., Amsterdam and UniCredit Bank - hold more than $60 \%$ of the market share. Therefore, some of the most relevant green practices undertaken by these institutions will be presented.

The main facilities provided by the European Bank for Reconstruction and Development for financing green technologies in Romania were taken into consideration too.

\section{Banca Transilvania (BT)}

BT is the credit institutions with the largest market share in terms of net assets owned by all credit institutions in Romania $17.72 \%$ at end-2019 (NBR, 2020). The bank was founded in 1994 and the acquisition of Bancpost, the first Romanian stateowned bank that was privatised, is an important stage in its development (Banca Transilvania, 2019).

In order to assess its non-financial activity, BT issues annual reports based on the Global Reporting Initiative (GRI). In February 2020, BT launched the online platform www.bancatransilvania.ro/think where information about the bank involvement in sustainable activities is provided (Banca Transilvania, 2020). The BT environmentally friendly initiatives include financing of energy efficient projects and electric cars. The credit analyses of BT use a model to assess the environmental risks (Banca Transilvania, 2020a).

The green mortgage loan offered by the bank - "Creditul Verde" ("The Green Credit") - is granted both in lei (leu, the local currency) and euro. Besides this loan, the bank grants green personal loan for the purchase of facilities based on green technologies. These loans benefit from some cost advantages (Banca Transilvania, 2018).

Related to the environmental protection issues, it is worth mentioning that BT holds the international "green building" certification for certain of their spaces (Banca Transilvania, 2018a). In the same context, the bank participation to the forestation actions in Transilvania and Buzău in 2019 should be mentioned (Banca Transilvania, 2019a).

\section{Banca Comercială Română (BCR)}

The institution is the second largest bank in Romania with $14.43 \%$ market share in terms of net assets (end-2019) (NBR, 2020). BCR was established in 1990 as one of the most important state-owned bank, but after the privatisation process was bought by the Austrian bank Erste Bank.

BCR mentions that joined the United Nations Environment Programme - Finance Initiative (UNEP FI) in 1992 and that developed an "Environmental Procedure" for granting of loans; moreover, starting with 2009 the bank's environmental activities were directed towards more efficient use of water, electricity, paper, ecc., including introduction of ebanking (BCR, 2010).

The bank distinguishes itself with the first senior non-preferred bonds in Romania launched in 2019. One of the investors in this 600 million lei bond issuance was the European Bank for Reconstruction and Development (EBRD) (BCR, 2019). It is worth noting that the funds invested by the EBRD in these bonds 
(125 million lei, equivalent of 26 million euros) are directed towards green projects including certified residential and commercial projects (EBRD, 2019).

As part of its actions on the environment and responsible financing, the Erste Group uses the Energy Sector Principles to govern the activity in this sector. These principles are valid for $\mathrm{BCR}$ too (BCR, 2020). Therefore, recognising the importance of the energy sector for economy, $\mathrm{BCR}$ is involved in the financing of this sector. The energy efficiency projects include 48 loans granted under the EU/EBRD EEFF (Energy Efficiency Finance Facility) and 34 loans granted under the EU/EBRD RoSEFF (Romania - SME Sustainable Energy Financing Facility) (Erste Group, 2017).

\section{BRD-Groupe Société Générale (BRD)}

BRD is the third largest bank in Romania, with $11.28 \%$ market share in terms of net assets (end-2019) (NBR, 2020). The official website of the bank has a section dedicated to corporate social responsibilities (CSR) activities (https:/www.brd.ro/en/about$\mathrm{brd} /$ corporate-responsibility/the-civil-society). The bank is involved in projects that promote culture, education and sport in Romania. Projects designed to help children in difficult situations are also developed.

The BRD annual reports mention the actions taken towards environment protection. As part of the Société Générale Groupe, these actions rely on the group commitment to the responsible business model. The bank report (BRD, 2019) states that Société Générale is committed to support financing for the energy transition; also, in order to diminish the impact of its activity on environment, Société Générale developed the 2014-2020 carbon reduction program. According to this program, Société Générale will reduce $\mathrm{CO} 2$ emission by $20 \%$.

Against this background, BRD also takes actions to protect environment. These initiatives include measures to diminishing its $\mathrm{CO} 2$ emission and implementing of a program for collection and recycling of electric and electronic waste. The Equator Principles are applied by BRD since 2009 (BRD, 2019).

\section{ING Bank N.V., Amsterdam}

ING Bank N.V., Amsterdam is the most important branch of a foreign credit institution in Romania, accounting for $9.01 \%$ of total net assets (end-2019) (NBR, 2020).

The environmental policy of this branch is consistent with the environmental policy conceived by the ING Group. ING developed an Environmental and Social Risk Framework that applies not only to all its products and business, but also to all its branches and majority-owned legal entities. This framework includes the description of the environmental and social risk assessment of their clients' activities. The Equator Principles were adopted by ING in June 2003 (ING, 2019).

ING promotes sustainable business. The measures are directed to reducing its environmental footprint, but also to financing sustainable business. ING is strongly committed towards climate actions; therefore, the bank has financed billions of euros for renewable energy projects, green buildings, electric vehicles, waste water treatment ecc. (ING, 2020). ING pays attention to climate change issues. Therefore, since 2017 , ING issues annual reports on climate change based on the recommendations of the Financial Stability Board's (FSB) Task Force on Climate-related Financial Disclosures (ING Groep N.V., 2020).

ING Bank's actions in Romania to promote sustainability include sustainable financing designed to meet the objectives of the Paris Agreement. It is worth mentioning that ING Bank contributed to the first issuance of green bonds in Romania (500 million euros). In addition, similar to other banks, ING Bank is concerned to diminishing the negative impact of its activities on environment. This approach is also reflected in the procurement policy (ING Bank N.V. Amsterdam, 2020).

\section{UniCredit Bank}

UniCredit Bank is a credit institution with majority foreign capital, which is part of the UniCredit Group. The bank accounts for $8.99 \%$ of total net assets (end-2019) (NBR, 2020), being one of the largest bank in Romania.

The initiatives undertaken by UniCredit Groupe towards a more environmental-friendly policy have more dimensions. Several actions are related to reducing the bank impact on environment through internal measures such as reducing greenhouse gas emissions and use of paper. UniCredit adhered to the principles promoted by the Task Force on Climate-Related Financial Disclosures and Principles for Responsible Banking. Another agreement was signed with OECD Business for Inclusive Growth Coalition. The policy of UniCredit has been pursuing the increase of the exposures towards sustainable projects such as energy efficiency loans. The exposure towards the renewable energy projects is set to increase by $25 \%$ by 2023 (UniCredit, 2019).

UniCredit Bank in Romania offers the green loan "Creditul verde pentru casă" ("Green home loan") to finance a home built after January 1, 2020, which detains an A or B + energy efficiency certificate. The maximum value of the loan is 250,000 euros, and the maximum maturity, 30 years. An advance of at least $15 \%$ is required. The loan is denominated only in local currency; in the first 5 years the interest rate is fixed and in the following years, variable (UniCredit Bank, 2020).

The green loans offer in the Romanian banking system include other green loans too, such as Creditul imobiliar "Casa ta verde" (Loan „Your green house”) from Raiffeisen Bank (Raiffeisen Bank, 2020). Comparing UniCredit's offer with Raiffeeisen Bank's offer, one can notice that there are many similarities between the two green loans.

Green loans are advantageous for both customers and banks. The benefits of the customers buying energy-efficient homes include: lower interest rates, lower heating/cooling costs, and higher market value. The banks benefit from an investment with lower risk (EBRD, GEFF, 2019).

\section{European Bank for Reconstruction and Development (EBRD) green facilities}

The facilities provided by the EBRD have an important role in financing green technologies in Romania. In 2017, the EBRD launched the Green Economy Financing Facility (GEFF) designed to provide loans to support residential sector projects for energy efficiency (EBRD, 2017).

The Energy Efficiency Finance Facility in Romania (EEFF) was launched in 2008 to support the companies' energy efficiency projects. The local partners of EBRD involved in this facility are: BT, BCR, BRD, CEC Bank, Raiffeisen Bank and OTP Bank. Another credit facility was launched in 2011: Romania Sustainable Energy Financing Facility (RoSEFF). This credit facility targets the small and medium enterprises intending to invest in energy efficiency projects. BCR was the first partner of the EBRD in this facility (Grytsenko, 2011). 
Nevertheless, the development of green banking in Romania implies the raise of general awareness towards green economy and green banking products. To this end, the survey carried out by the EBRD's consultants in 2017 among exhibitors selling apartments and houses in Bucharest is relevant. The survey results indicate that only several of these exhibitors were informed about the Energy Performance Certificates rating of the homes they were selling (EBRD, GEFF, 2019).

\section{CONCLUSIONS}

To achieve the goals of the Paris Agreement on climate change and the UN 2030 Agenda for Sustainable Development urgent actions should be taken.

In this context, the financial system is called to sustain the orientation to a more sustainable economy. The European Green Deal has emphasised the importance of green finance that should support the EU transition to a greener economy.

Green finance is an emerging area that requires better understanding and knowledge from the part of all stakeholders, including financial institutions, central banks, financial and banking regulators, regional development banks, customers.

Banks in Romania make effort to be environmentally friendly and to be involved in financing of some green projects, such as the energy efficient projects. Many credit institutions in Romania are part of international financial groups and, consequently, their policy takes into account the strategy of sustainability at the group level.

\section{REFERENCES}

1. Banca Transilvania (2020) Rezultatele financiare preliminare BT la 31 decembrie 2019, Press release 27.02.2020. Retrieved from https:/www.bancatransilvania.ro/bt-social-medianewsroom/stiri/rezultatele-financiare-preliminare-bt-la-31decembrie-2019-/.

2. Banca Transilvania (2020a) We have the courage to change things. Retrieved September 8, 2020, from: https://www.bancatransilvania.ro/think/en/.

3. Banca Transilvania (2019) Banca Transilvania and Bancpost became one bank, Press release 2019-01-02. Retrieved from https://www.bancatransilvania.ro/bt-socialmedia-newsroom/en/news/banca-transilvania-andbancpost-became-one-bank.

4. Banca Transilvania (2019a) Raport non-financiar de mediu, social şi de guvernanţă 2019. Retrieved from https://www.bancatransilvania.ro/files-aga/situatiifinanciare-consolidate-si-individuale-la-31-decembrie2019/6.raport_nonfinanciar_de_mediu_social_si_de_guver nanta_2019.pdf.

5. Banca- Transilvania (2018) Cum să-ţi iei o locuinţă “verde”, Retrieved https://www.bancatransilvania.ro/blog/educatiefinanciara/cum-sa-ti-iei-o-locuinta-verde-/.

6. Banca Transilvania (2018a). Raport non-financiar de mediu, social şi de guvernanţă 2018. Retrieved from https://www.bancatransilvania.ro/files/carte-devizita/raportnonfinanciardemediusocialsideguvernanta201 8.pdf.

7. Bădulescu, D., Bădulescu, A., Morutan, R.A. (2017) Sustenability in Romanian Banking: A Promising New Business Model or "Business as Usual"?, BASIQ International Conference: New Trends in Sustainable
Recently, under the COVID-19 crisis, the Romanian banks have been intensifying their efforts to promote internet and online banking, with positive impact on consumption of paper and energy.

The credit line facilities provided by the EBRD for financing green technologies play an important role in development of green banking in Romania.

However, the green banking products in Romania are still in the emerging stage. Banks should improve and diversify their offer of green products and services. In parallel, the marketing initiatives to promote green products should be intensified. Improving the expertise to assess green projects might contribute to green banking development. Several incentives, including a preferential regulatory regime for green assets might stimulate banks to finance these projects. Some mandatory requirements for banks to be involved in green financing might be an efficient tool to promote green banking in Romania. Similarly, the advantages of the borrowers seeking green projects should be strengthened.

Besides these measures, increasing awareness towards environmentally friendly behaviour at all levels is a key-factor to achieve the development of green banking in Romania. To this end, implementing of ample educational programs targeting large and diversified categories might be useful.

Business and Consumption - 2017, Proceedings of BASIQ, 80-87, Graz, Austria.

8. BCR (Banca Comercială Română), Responsible funding, (2020). Retrieved October 29, 2020, from: https://www.bcr.ro/en/csr/vision/responsible-funding.

9. BCR (Banca Comercială Română), BCR launches the first ever non-preferred bond issuance in Romania and CEE region with a value of RON 600 million, Press release, 16 December, (2019). Retrieved from https:/www.bcr.ro/en/press/press-release/2019/12/16/bcrlanseaza-prima-emisiune-de-obligaiuni-neprefereniale-dinromania.

10. BCR (Banca Comercială Română), Raport de responsabilitate socială corporativă 2009/2010, (2010). Retrieved

from https:/www.bcr.ro/content/dam/ro/bcr/www bcr ro/CSR/ Rapoarte/Raport BCR CSR RO 2009 2010.pdf.

11. BRD (BRD-Groupe Société Générale), Annual Board of Directors' Report 2018, (2019). Retrieved from https://www.brd.ro/_files/pdf/2.2\%20BoD\%20report\%202 018\%20EN.pdf.

12. EBRD (European Bank for Reconstruction and Development), Banca Comerciala Romana - Senior nonpreffered bonds(f), 18 December, (2019). Retrieved from https://www.ebrd.com/work-withus/projects/psd/51399.html.

13. EBRD (European Bank for Reconstruction and Development), Launch of Green Economy Financing Facility in Romania, 27 June, (2017). Retrieved from https://www.ebrd.com/news/events/green-economyfinancing-facility-in-romania.html.

14. EBRD (European Bank for Reconstruction and Development), GEFF (Green Economy Financing Facility), EBRD blazes a trail for green household investment in Romania, 28.02.2019, (2019). Retrieved from 
https://ebrdgeff.com/romania/geff_promotes_green_mortg ages- $2 /$.

15. Erste Group, Financing Energy Efficiency projects in Romania, October, (2017).

16. European Commission, COMMUNICATION FROM THE COMMISSION TO THE EUROPEAN PARLIAMENT, THE EUROPEAN COUNCIL, THE COUNCIL, THE EUROPEAN CENTRAL BANK, THE EUROPEAN ECONOMIC AND SOCIAL COMMITTEE AND THE COMMITTEE OF THE REGIONS, Action Plan: Financing Sustainable Growth, Brussels, 8.3.2018 COM(2018) 97 final, (2018). Retrieved from https://ec.europa.eu/transparency/regdoc/rep/1/2018/EN/C OM-2018-97-F1-EN-MAIN-PART-1.PDF.

17. European Commission, European Commission establishes an expert group to develop a comprehensive European strategy on sustainable finance, Press release, Brussels, 28 October, (2016). Retrieved from https://ec.europa.eu/info/sites/info/files/161028-pressrelease en.pdf.

18. Frecea, G. L., Schipor C., Corporate Social Responsibility - The Romanian Banking Sector Perspective, Management Intercultural, Vol. XIX, No. 39, 155-162, (2017).

19. G20 Green Finance Study Group, G20 Green Finance Synthesis Report, 15 July, (2016). Retrieved from http://www.g20.utoronto.ca/2016/green-financesynthesis.pdf.

20. Grytsenko, S., EBRD recognises best sustainable energy projects in Romania, News, 12 December, (2011). Retrieved from https:/www.ebrd.com/news/2011/ebrdrecognises-best-sustainable-energy-projects-inromania.html.

21. HLEG (EU High-Level Expert Group on Sustainable Finance), Financing a Sustainable European Economy, Final Report 2018, (2018). Retrieved from https://ec.europa.eu/info/sites/info/files/180131sustainable-finance-final-report_en.pdf.

22. ING, Sustainable business, (2020). Retrieved November 15, 2020, from: https://www.ing.com/Sustainability/Sustainablebusiness.htm.

23. ING Groep N.V., ING Climate risk report 2020: Our approach to climate risk management, updated 12 October, (2020).

24. ING, Environmental and Social Risk Framework, Policy, Version June 2019, (2019). Retrieved from https://www.ing.nl/media/ING-Environmental-and-SocialRisk-Framework_tcm162-175186.pdf.

25. ING Bank N. $\bar{V}$. Amsterdam, Finanţare sustenabilă. Amprentă de carbon diminuată. Voluntariat, Sucursala Bucureşti, (2020). Retrieved November 15, 2020, from: https://ing.ro/ing-in-romania/sustenabilitate/actiuniclimatice.
26. Kandavel, D., Green banking initiatives of commercial banks in India, SIT Journal of Management, Vol. 3, No. 2, 213-225, (2013).

27. Lindenberg, N., Definition of Green Finance, Deutsches Institut für Entwicklungspolitik/German Development Institute, April, (2014). Retrieved from https://www.cbd.int/financial/gcf/definitiongreenfinance.pdf.

28. Mohd, S., Kaushal, V.K. (2018) Green finance: A Step towards Sustainable Development, MUDRA: Journal of Finance and Accounting, Vol. 5, No. 1, 59-74.

29. NBR (National Bank of Romania) (2020). Annual Report 2019.

30. Ngong, C. A., Thaddeus, K. J. (2020) Climate Change and Sustainable Green Banking in BRICS Countries, International Journal of Research Publications, Vol. 52, No. 1.

31. Park, H., Kim, J.D. (2020) Transition towards green banking: role of financial regulators and financial institutions, Asian Journal of Sustainability and Social Responsibility, Springer, Vol. 5, No. 1.

32. Raiffeisen Bank (2020). Creditul imobiliar Casa Ta Verde, (2020). Retrieved October 28 from: https://www.raiffeisen.ro/persoane-fizice/produselenoastre/credite/credite-imobiliare/credit-imobiliar-casa-taverde/.

33. Tara, K., Singh, S., Kumar, R. (2015) Green Banking for Environmental Management: A Paradigm Shift, Current World Environment, Vol. 10, No. 3, 1029-1030.

34. UNEP (2016) Inquiry, Definitions and Concepts: Background Note, Inquiry Working Paper 16/13, September. Retrieved from http://unepinquiry.org/wpcontent/uploads/2016/09/1_Definitions_and_Concepts.pdf.

35. UniCredit Bank (2020), Créditul verde pentru casă, (2020). Retrieved October 28, from: https://www.unicredit.ro/ro/persoanefizice/Campanii/creditul-verde.html.

36. UniCredit (2019) UniCredit announces new ESG targets as part of a long-term commitment to sustainability: Do the right thing! Press release, 26 November. Retrieved from https://www.unicreditgroup.eu/en/press-media/pressreleases/2019/unicredit-announces-new-esg-targets-aspart-of-a-long-term-commi.html.

37. Wang, Y., Zhi, Q. (2016) The role of green finance in environmental protection: Two aspects of market mechanism and policies, Energy Procedia, Vol. 104, December, 311-316. 